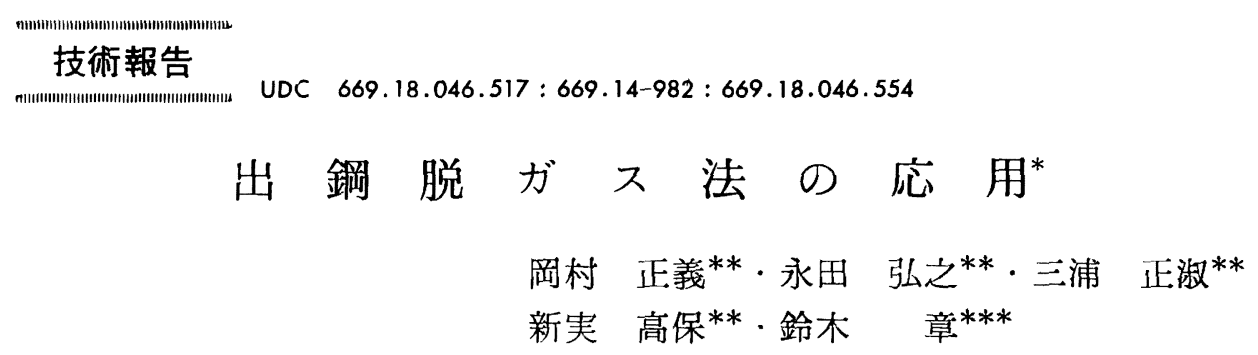

\title{
Some Applications of Tap Degassing Process
}

\author{
Masayoshi Oкamura, Hiroyuki Nagata, Masatoshi MiURA, \\ Takayasu NIIMI, and Akira SUzUKI
}

\section{Synopsis:}

Behaviour of hydrogen, oxygen, and nitrogen in tap degassing process is studied and the efficiency of the process is found equivalent to the other processes. The degassing steps are divided into two parts. That is, the first is the birth and fall of droplets and the second is the degassing through the free surface of molten bath. The violent motion of the droplet at the first stage is very important. The applications to the desulphurization treatment, $\mathrm{Al}$ addition technique and the production of low carbon stainless steel are also discussed.

1. 緒容

近年の特殊精鍊法の発達によつて従来の高級鋼の製鋼 体系であつた転炉または電弧炉と真空脱ガス処理の組み 合わせから転炉または電弧炉と特殊精鍊法の製鋼体系に 遂次変化しているのが現状であろう。これら特殊精錬炉 は精錬について脱ガス（脱酸，脱水素）に加えて脱硫が 可能であり，さらに一層の脱酸，脱水素の強化を目指す ものである. しかもこれらを達成するためには溶鋼の加 熱保温が必要であり, 特殊精錬炉は加熱装置を付带して いるのが通常である。

当高砂事業所では発電機，化学プラント，製鉄機械， 舶用部品などの大形化に対処するため 1975 年新大形鋳 鍛鋼工場を完成し $500 \mathrm{t}$ の超大形鋼塊の製造が可能であ る.この新工場には超大形鋼塊の製造上欠くことのでき ない保持炉を有しており，この保持炉は特殊精鍊の範ち ゆうに入り脱酸, 脱硫に対し有効な設借である 合湯にて超大形塊鋼を製造するためには最終ヒートは保 持炉を経由しないため，いわゆる電弧炉と出鋼脱ガス装 置にて溶製している．したがつてこの最終ヒ一トの溶鎦 は保持炉を経由する溶鋼に比較して脱酸, 脱硫に対し若 干劣る䀣念がある．そこでこの出鋼脱ガス装置の特性を 十分に理解しさらにこの適用範囲を拡大し特殊精鍊法に
匹敵する精鎳效果を持たせることは健全な超大形鋼塊の 製造に対して重要な意味を持つてくると考えられる. そ こで本報告では出鋼脱ガス法の基本的な考方方を整理す るとともに，この応用について $2 ， 3$ の検討を行なつた。

\section{2. 出鋼脱カス装置の脱ガス挙動と脱ガス機構}

\section{$2 \cdot 1$ 出銅脱ガス法の概要}

出鋼脱ガス法は Fig. 1 に示すようにストッパーをと り付けた中間取鍋を気密な注入用取鍋の上部にとり付け 取鍋を排気したのち溶銅を中間取鍋に出鋼し，ストッパ 一を開いて溶鋼を流啤脱ガスしながら真空取鍋内に注入 する方法である。

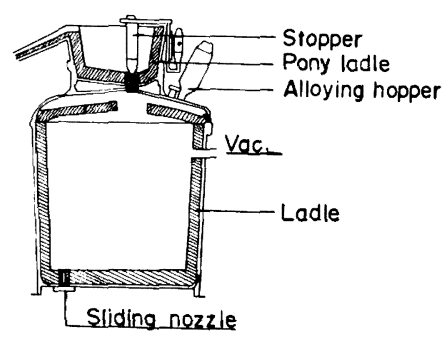

Fig. 1. Schematic drawing of tap degassing apparatus.

* 昭和 51 年 4 月本会輩演大会にて発表 昭和52年 5 月 26 日受付 (Received May. 26, 1977)

** (株) 神戸製鋼所 (Kobe Steel, Ltd., 2-3-1 Niihama Arai-cho Takasago 676)

*** (株) 神戸製鋼所工博 (Kobe Steel, Ltd.) 
Table 1. Main specification of $100 \mathrm{t}$ T. D unit.

\begin{tabular}{|c|c|c|}
\hline Classification & Item & Specification \\
\hline Ladle & $\begin{array}{l}\text { Inside diameter } \\
\text { Height } \\
\text { Refractory }\end{array}$ & $\begin{array}{l}2932 \mathrm{~mm} \\
3386 \mathrm{~mm} \\
\text { Zircon or High } \\
\text { Alumina }\end{array}$ \\
\hline $\begin{array}{l}\text { Vacuum pump } \\
\text { system }\end{array}$ & $\begin{array}{l}\text { Steem ejector } \\
\text { Capacity } \\
\text { Attainable pressure }\end{array}$ & $\begin{array}{l}\text { 6-stage steem } \\
\text { ejectors } \\
500 \mathrm{~kg} / \mathrm{h} \text { at } \\
0.5 \text { Torr } \\
0.05 \text { Torr }\end{array}$ \\
\hline Degassing & Time & $5 \sim 10 \mathrm{~min}$ \\
\hline
\end{tabular}

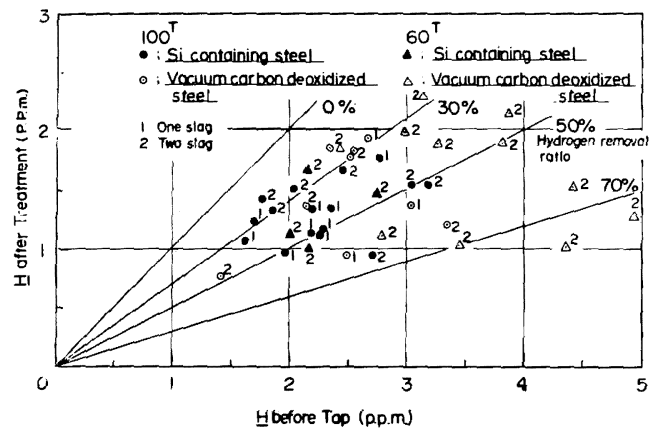

Fig. 2. Hydrogen behaviour in the tap degassing treatment.

したがつてこの装置は機構上他の脱ガス法に比較して 1）温度降下が少なく出鋼温度をことさら高くする必要 がほとえどなく，2）真空処理時間が非常に短かい3） 真空処理中あるいは処理後に合金元素や結晶粒度調整抄 または仕上脱酸削を加えることができるという特徽があ る.

なお $100 \mathrm{t}$ 出鋼脱ガス設糔の諸元を Table 1 に示す.

\section{$2 \cdot 2$ 出釾脱ガス装羁の脱ガス挙功}

\section{$2 \cdot 2 \cdot 1$ 水 素}

Fig. 2 に出銅脱ガス処理前後の $\mathrm{H}$ の挙動を示す. Fig. 2 における出鋼前の溶鋼の温度は $1650 \sim 1710^{\circ} \mathrm{C} の$ 範囲で, 温度降下は $60 \mathrm{t}$ 炉の場合平均 $70^{\circ} \mathrm{C}, 100 \mathrm{t}$ 炉 の場合 $60^{\circ} \mathrm{C}$ である. Fig. 2 に示すように脱水素率は $30 \%$ 以上で $50 \%$ 以上の脱水素率を得ることもできる. 処理後の 与る欠陷はない，図中含 $\mathrm{Si}$ 銅と真空炭素脱酸鋼とを比 較しているが，とくに大きな差は認められない。なお， 出鋼前の $\mathrm{Si}$ は約 $0.1 \%$ 以下で，含 $\mathrm{Si}$ 鋼の場合は出鋼 脱ガス中にホッパーより $\mathrm{FeSi}$ を添加し約 $0.25 \%$ に調 整している。
また，Fig. 2 で One slag 法と Two slag 法との比較 を示している. 後述するように One slag 法の場合には 出鋼前の O が Two slag 法に比較して高いため, 出鋼直 前に $\mathrm{Al}$ を使用しているが，処理後の吕は同レベルであ る.さらに $60 \mathrm{t}$ 炉と $100 \mathrm{t}$ 炉の比較については， $60 \mathrm{t}$ 炉と $100 \mathrm{t}$ 炉の単位時閒当りの溶鋼の処理量の比は 1 : 1.7 であるが，脱水素率に大きな差は認められない。

なお脱水素率におよぼす出鋼前の $\mathrm{O}$, 出鋼脱ガス過程 の脱酸量の影響について調查したが，相関は認められな かつた.

\section{$2 \cdot 2 \cdot 2$ 酸 素}

Fig. 3 に One slag 法, Two slag 法の纠鋼前のC と ○の関係を示す。このように Two slag法の場合には平 均的には $P_{\mathrm{co}}=1 \mathrm{~atm}$ に見掛上平衡している. 一方 One slag 法の場合にはなお過剩酸素を含んでおり， $P_{\mathrm{co}}=1$ atm 以上の酸素を有している，Fig. 4 に One slag 法,

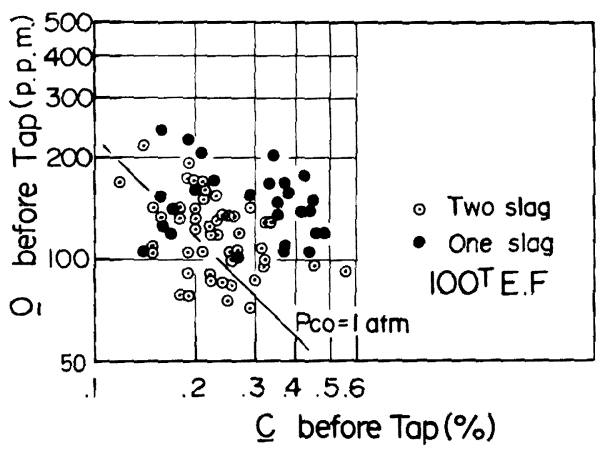

Fig. 3. Relation between $\mathrm{C}$ and $\mathrm{O}$ before tapping in electric arc furnace.

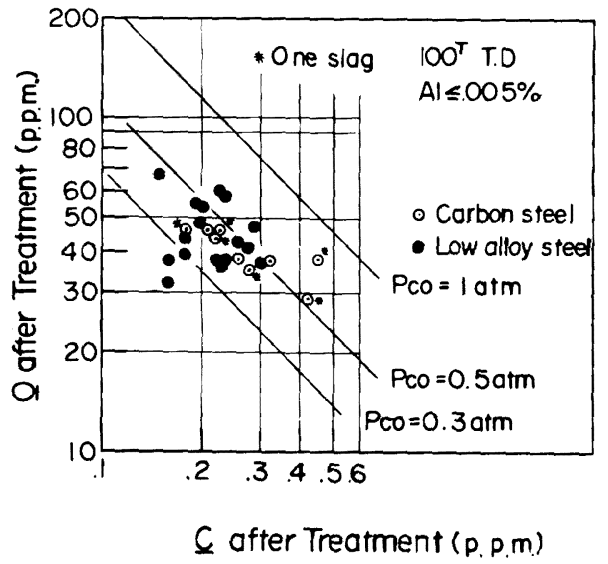

Fig. 4. Relation between $\mathrm{G}$ and $\mathrm{O}$ in the tap degassing treatment. 


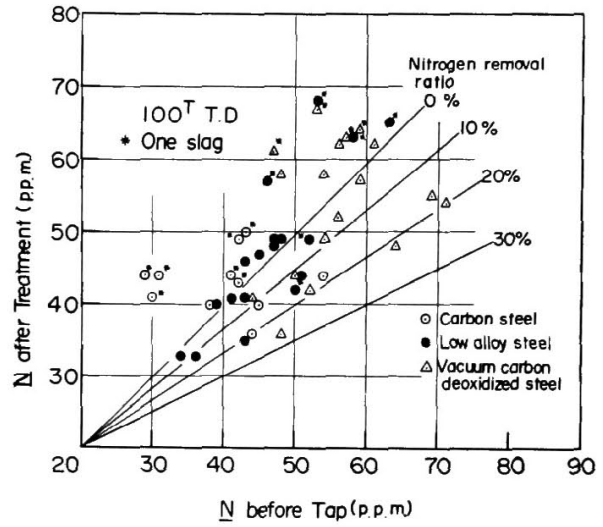

Fig. 5. Nitrogen behaviour in the tap degassing treatment.

Two slag 法の出鋼脱ガス後の $\mathrm{C}$ と $\mathrm{O}$ の関係を示す. こ の図より Oは平均値として $40 \mathrm{ppm}$ を示し， $P_{\mathrm{co}}=0.3$ $0.5 \mathrm{~atm}$ に見掛上平衡している. 図中 Fig. 3 で示した ような One slag 法, Two slag 法の差は認められな い. 従来 $\mathrm{DH}^{2)}$, $\mathrm{RH}$ 脱ガス装置の $\mathrm{O}$ 低炭素レベルて $P_{\mathrm{co}}$ が $0.1 \sim 0.2 \mathrm{~atm}$ に相当し，Cが增加すると $0.5 \mathrm{~atm}$ 程度に相当すると報告されており，このように出鋼脱ガ ス時の $\mathrm{O} も$ 他の脱ガス装置の脱酸能とほぼ同様と考えて よい.

\section{$2 \cdot 2 \cdot 3$ 窒 素}

Fig. 5 One slag 法, Two slag 法の出鋼前と山鋼 脱ガス処理後の Nの関係を示す. One slag 法と Two slag 法を比較した場合には明らかに One slag 法の方 が処理後のNが高い. One slag 法の場合には前述した ように出鋼前に過剩酸素を含えでいるので，この過剩酸 素を除くことを目的として, 処理後の鋼中に $\mathrm{Al}$ が残留 しない程度（0.005\% 以下）に出鋼前に Al を添加して いる.したがつて One slag 法の場合には出鋼時におけ る電弧炉から中間取鍋間のNの吸収が Two slag 法に比 較して多いと考えられる. すなわち Two slag 法の場合 には電弧炉から中間取鍋までに一方はあり变化しないの に対し, One slag 法の場合にはこの過程で脱酸が一部 進行しており，正值は低くなつていると考えられる．促 来N吸収速度は $\mathrm{O} に$ 強く影響されると報告されてお り3) One slag 法の場合この出銅過程におけるNの吸收 が無視し党ず結果的に処理後のNが高くなつていると荡 えられる.

一方 Two slag 法の場合には出鋼脱ガスによつて脱窒 反応が進行している.すなわち最大 $30 \%$ 程度の脱窒が 生じている. Two slag 法の場合にも出鋼過程でNは吸
收されるため実際にはこれ以上の脱窒反応が進行してい るものと考兄らる. 参考までに Two slag 法で大気出 鋼した場合のNの増加量は平均 $13 \mathrm{ppm}$ である. 従来 DHでの脱窒反応は 60ppm 以下では進行しないという 報告があり4)，この点からも出鋼脱ガスは効果的な脱力゙ ス法であるといえる.

\section{$2 \cdot 3$ 出鋼脱ガス装置の脱ガス機構}

以上述べたように出鋼脱ガス装置の脱ガス効果は DH RH などの他の脱ガス装置と比較しても全く澵色のない ものである.そこでこの出鋼脱ガス時の脱ガス㙨構につ いて脱水素の面から若干の検討を行なう.

出鋼脱ガス過程における液滴の飛散状況は設備の関係 上直接観察することはできない.しかし真空鋳造過程に おいてはノズルから真空中に溶鋼か入る瞬間の液滴の状 況を直接観察することはできないが，ノズル先端から約 $500 \mathrm{~mm}$ 以降の状況は観察できる. Photo. 1 に液滴の飛 散状況の1例を示す. ノズル先端から $500 \mathrm{~mm}$ 程度の

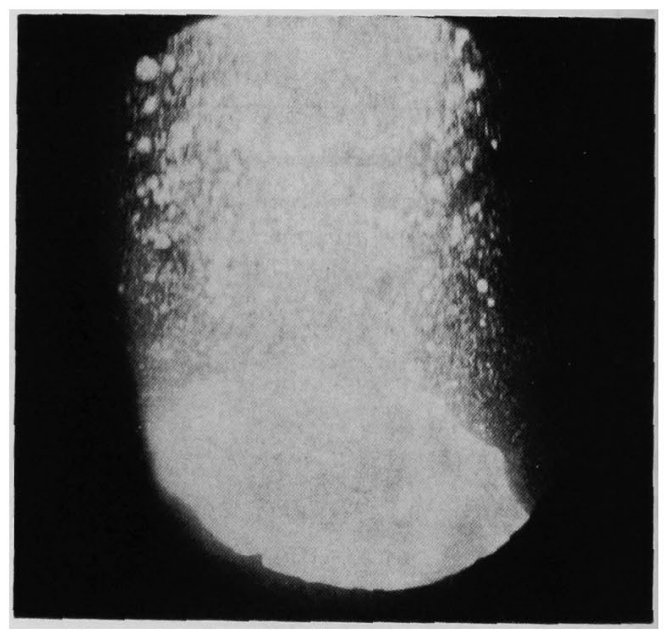

Photo. 1. Droplet during vacuum casting.

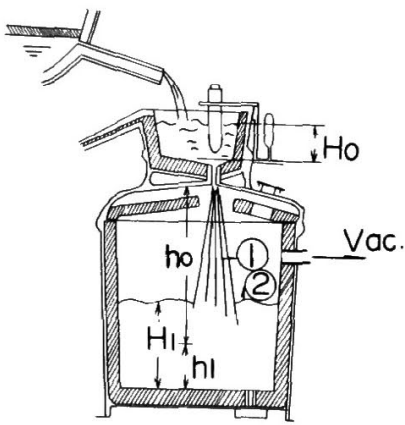

Fig. 6. Degassing step and the notation. 
所でほぼ最終の液滴の状況を示しており，上くにてれ以 降で液㵜がさらに激しく飛散を続けるようではない，こ のような状況は出龬脱ガス過程でも生じていると推定さ れ，溶鋼が真空中に入つた瞬間に液滴化されているもの と若えられる。

脱水素反応に関する研究は $H$. KNÜPPEL and $F$. OETERs $^{5)}, Y u . V$. TARAKANov and $B . V$. LincheVsKiI ${ }^{6)}$, $M$. Boorstein and $R . D$. PeHLKE ${ }^{7)}$, 鈴木, 谷口 ${ }^{8)} ら の$ 研究があり，この反応は溶鋼中の物質移動律速と報告さ れている. 一方流滴脱ガスに関する研究は前川，中川， 福本，谷口9)および大井 ${ }^{10)}$ の報告があり，とくに大井ら は液滴内部に溶鋼の流動がない場合および流動がある場 合についてとの脱ガス効㑐におよぼす影響について論じ ている.

出鋼脱ガス過程におけるHの放出はFig. 6 亿示方よ うに2段階で行なわれる. 寸なわち1）液滴の生成打よ び落下時，2）落下後の溶鋼の表面からの放出である.

龷の放出反応は溶鋼中の物質移動律凍であり, 1 次反 忘に往う。

$$
-d \mathrm{H} / d t=k_{\mathrm{H}} \cdot A / V \cdot\left(\underline{\mathrm{H}}-\underline{\mathrm{H}}^{*}\right)
$$

ここで,

$$
\begin{aligned}
k_{\mathrm{H}} & : \mathrm{H} \text { 物質移動係数 }(\mathrm{cm} / \mathrm{sec}) \\
A & : \text { ガスーメタル界面積 }\left(\mathrm{cm}^{2}\right) \\
V & : \text { 溶罁および液滴の体積 }\left(\mathrm{cm}^{3}\right) \\
\underline{\mathrm{H}} & : \text { 時間 } t \text { における } \mathrm{H}(\mathrm{ppm}) \\
\mathrm{H}^{*} & : \text { 平衡 } \mathrm{H}(\mathrm{ppm})
\end{aligned}
$$

(1)式を積分し $H^{*} \approx \mathrm{O}$ とすると次式が得られる.

$$
\ln \underline{\mathrm{H}} / \underline{\mathrm{H}}_{\mathrm{O}}=-k_{\mathrm{H}} \cdot(\mathrm{A} / \mathrm{V}) \cdot t
$$

そこでまず溶鋼表面からの县の放出について検討子る。 この場合（2)式は（3)式に変換される.（ここで $h_{1}=$ $1 / 2 H_{1}$ と仮定する. $H_{1}$ : 出鋼脱ガス終了時の溶鋼深さ, $(\mathrm{cm}))$

$$
\ln \mathrm{H} / \mathrm{H}_{\mathrm{O}}=-k_{\mathrm{H}} \cdot 1 / h_{1} \cdot t
$$

(3)式を計算するにあたり $k_{\mathrm{H}}$ の值が必要となる.そこ で $k_{\mathrm{H}}$ の值はHigbie の浸透説を用いる.

$$
k_{\mathrm{H}}=2(D / \pi \theta)^{1 / 2} \text {. }
$$

ここで,

$$
D \text { : 水素の㕬散係数 }\left(\mathrm{cm}^{2} / \mathrm{sec}\right)
$$$$
\theta \text { : 表面更新時間 }(\mathrm{sec})
$$

そこでDの值を前川, 中川, 福本, 谷口らの $1 \times 10^{-3}$ $\left(\mathrm{cm}^{2} / \mathrm{sec}\right)^{9)}$ 用いて (3), (4) 式より求めた $k_{\mathrm{H}}, 1$ H/ $\underline{H}_{0}$ と $\theta$ の結果を Fig. 7 に示す. 最近鈴木らは小 型試験の結果, $k_{\mathrm{H}}$ の值として $1550^{\circ} \mathrm{C}, 1580^{\circ} \mathrm{C}$ でそ れぞれ $0.98 \times 10^{-2}, 1.04 \times 10^{-2} \mathrm{~cm} / \mathrm{sec}$ の值を報告し ている8). Fig. 7 において $\theta$ が $1 \mathrm{sec}$ の場合でも脱水素

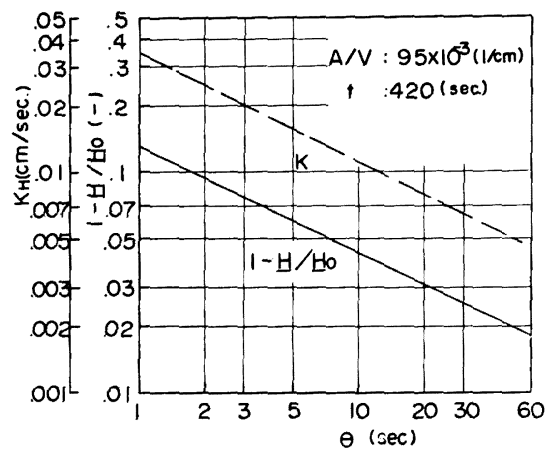

Fig. 7. Relation between hydrogen removal ratio, mass transfer coefficient and surface renewal time.

萃は $10 \%$ 程度であり，溶鋼表面からの水素の放出は比 較的少ない.

次に液滴の生成および落下時における水素の放出につ いて検討与る。この場合液滴の落下時間を次式11から推 定する.

$$
t_{\mathrm{O}}=\left[\left(H_{\mathrm{O}}+h_{\mathrm{O}}\right)^{1 / 2}-H_{\mathrm{O}}^{1 / 2}\right] \cdot(2 / g)^{1 / 2}
$$

ここで,

$$
\begin{aligned}
t_{\mathrm{O}} & \text { : 液滴の㵲留時間 }(\mathrm{sec}) \\
H_{\mathrm{O}} & : \text { 中間取鍋内の溶鋼高さ }(\mathrm{cm}) \\
h_{\mathrm{O}} & : \text { 液滴の落下距難 }(\mathrm{cm}) \\
g & : \text { 重力速度 }\left(\mathrm{cm} / \mathrm{sec}^{2}\right)
\end{aligned}
$$

(5)式以諸元を代入すると約 $0.3 \mathrm{sec}$ となる。そこで仮 りに $\theta$ を $0.3 \mathrm{sec}$ とし (4) 式より $k_{\mathrm{H}}$ を計算すると 6.5 $\times 10^{-2} \mathrm{~cm} / \mathrm{sec}$ となる. そこで液榈の生成，落下時の水 素の放出に対しては（2)式は（6)式に変換される.

$\ln \underline{\mathrm{H}} / \mathrm{H}_{\mathrm{O}}=k_{\mathrm{H}} \cdot 3 / r \cdot t$

ここで, $r$ : 液滴の半径 $(\mathrm{cm})$

そこで（6)式に上記 $k_{\mathrm{H}}$ 值， $t_{\mathrm{O}}$ の值をそれててれ代入して 1- $\underline{\mathrm{H}} / \mathrm{H}_{\mathrm{O}}$ と $r$ の関係を Fig. 8 亿示与. この結果より 脱水素染 $50 \%$ を得るた汹液滴の半径は平均 $1 \mathrm{~mm}$ でなければならない。しかし前川ら9）も流滴脱ガスの研 究で指摘しているように，実际にはこのような小谁にな つているとは考えられない，寸な执ち液滴の生成から落 下終了末での反忘を単に滯留時間，液洞の大きさ，なら びに若干の液滴の運動を考慮した程度では説明できな い.

化学:工学の分野では液滴生成㭙の物質移動速度がきわ めて大きいことは実呀的に破かめられて扮り ${ }^{12)}$ ，また気 泡生成時の物質移動が大きいことも確かめられている13) とくに前者については接触面積の変化更新，ノズル貲出 による液滴内流動, 界面の不安定さなどの現象の複雑さ 


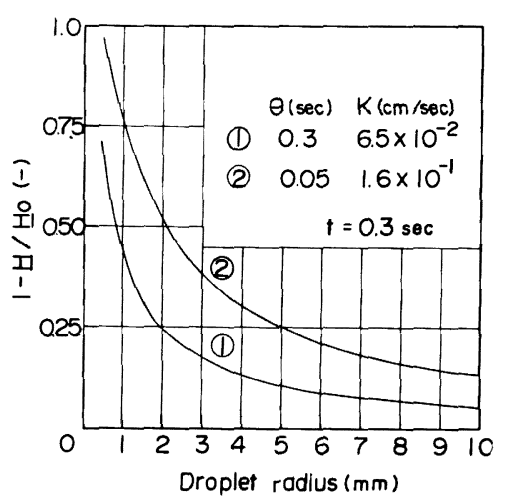

Fig. 8. Relation between hydrogen removal ratio and droplet radius.

のために十分に解明されてはいない。そこで仅に $\theta$ を $0.05 \mathrm{sec}$ とすると $k_{\mathrm{H}}$ は $1.6 \times 10^{-1} \mathrm{~cm} / \mathrm{sec}$ となり，そ こで同様の計算で $1-\underline{H} / \underline{H}_{O}$ と $r$ の関係を求めた結壮 を Fig. 8 に示す. この結果より脱水素率 $50 \%$ を得る ためには液滴半径は約 $2 \mathrm{~mm}$ となる. 前川ら9) は流滴脱 ガス壯の脱水素機眻に閔与る報告で，CO 気泡中への水 秦の放出による脱水素効果が無視しえない因子であると 述べているが，てれとともに本試算結果からもわかるよ うに液㵜生成時の運動の激しさも水素の放出に対して無 視しえないものと考えられる。

以上のように出鋼脱ガス装置の脱ガスは溶鋼が中間取 鍋から真空中に入つた瞬間から落下時に生じていると考 元られ，他の脱ガス装置と比較して全く遜色のない脱ガ 又効果が得られる.

\section{3. 出鋼脱ガス法の応用}

以上のように出鋼脱ガス装置は他の脱ガス法に比較し て短時間 (5〜10 min) で同等の脱ガス刘怡が得られるた め種々の応用が可能である.

\section{$3 \cdot 1$ 脱 硫}

出鋼脱ガス時には前述したように溶鋼は流湤化され界 面積は非常に增加し，脱ガスはこの落下時にほぼ完了す ると考えられる.脱硫は一般的に溶鋼成分はもちろ九の こと塩基度， $(\mathrm{FeO}),(\mathrm{MnO}), \mathrm{O}$, 温度に依存しており 出鋼脱ガス装置で適当な処理をすればこの特徽を生かし て効果的な脱硫処理を行なうことができる14). そこで出 銅脱ガス装置の鍋底にあらかじめ乾燥した焼石灰と䖝石 の混合物を入れ犆き, 出鋼脱ガス処理と同時に脱硫を行 なう方法を検討した？その結果平均脱硫率として $45 \%$ が得られ，0.005\% 以下の極低硫鋼の俸造も可能であ る. またこの処理によつてHの増加, 温度降下の增加も

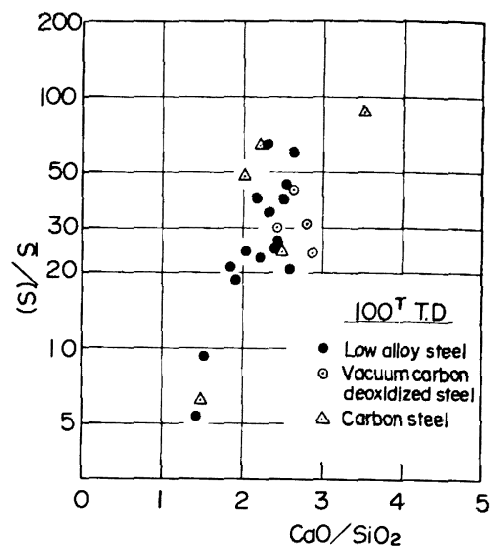

Fig. 9. Relation between $\mathrm{CaO} / \mathrm{SiO}_{2}$ and (S)/S at desulphurization treatment in tap degassing apparatus.

認められず，非常に良好な結壮を得ている. Fig. 9 にこ の処理による $(\mathrm{S}) / \mathrm{S}$ と $\mathrm{CaO} / \mathrm{SiO}_{2}$ の関係を示すが, 塩基度が 2.5 程度で分配比として $20 \sim 60$ 程度が得ら れる. この值は保持炉の結果1) と遜色のないものであ り，この処理による脱硫効果が顕著であることを示して いる.

\subsection{Al の制御}

$\mathrm{Al}$ は非常に活性な元素であるためこれを制御するこ 上は困難とされ，これまで㮔々の方法が検討されてき た・出鋼脱ガス装置の前述した特性を利用すれば, $\mathrm{Al}$ を 歩留りよく鋼中へ添加することができる.すなわち出銅 悦ガス処理を行ない十分脱酸, 脱水素を行なつた後, 鋼 ウに Ar を送り込みながら Al を添加することによつて 鋼中へ Al を安定して添加することができる．この方式 によつて Al 添加を行なつた結果を Fig. 10 に示す. こ の場合の Al の狙いは 0.023\% であり，士0.005\%の 䈤囲内に十分制御することができる。またこの場合の $\mathrm{Al}$ の歩留りは 70\% であり，本方式を採用することに

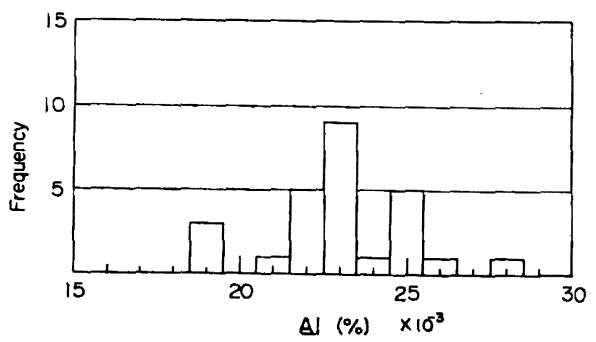

Fig. 10. Al frequency by $\mathrm{Al}$ addition after tap degassing treatment. 


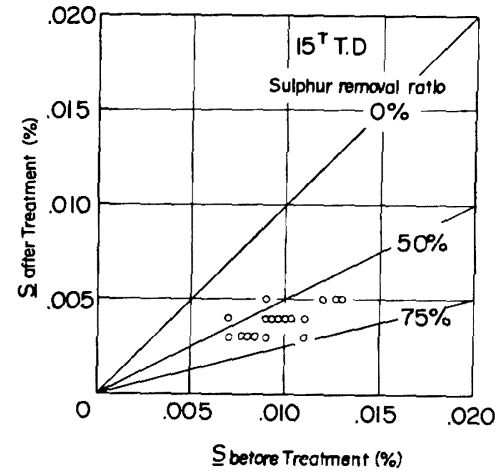

Fig. 11. Sulphur behaviour in tap degassing treatment.

より介在物の浮上も促進されるため，鍋下のOも $20 \mathrm{ppm}$ が達成され，非常に清浄な鋼の製造が可能である.

\section{3 低岸素鋼の製造}

最近の特殊精錬法の発達によつてステンレス鋼をはじ め極低炭素銅の製造が容易になつたが，出鋼脱ガス装置 によつても低炭素ステンレス鋼の製造が可能である。す なわち出鋼脱ガス処理前に未脱酸状態で出鋼しこの装置 内で激しい流滴化による CO 反応によつて $0.020 \% \mathrm{C}$ 以下の低炭素ステンレス鋼の製造も可能であり，この方 式と前述した脱硫法の組み合わせによつて 0.005\% S以 下の低硫ステンレス鋼の製造も可能である ${ }^{15)}$. この脱硫 法をステンレス鋼に適用した結果を Fig. 11 に示す.

\section{4. 結言}

出鋼脱ガス装置の脱ガス機構およびその応用について
述べたが，出鋼脱ガス装置は適当な処理を行なうことに よつて他の脱ガス装置と同等あるいはそれ以上の効果を 発揮させうることができる．当高砂事業所においては出 鋼脱ガス装置の特性を十分に発揮させ，保持炉と組み合 わせることにより健全なる超大形鋼塊の製造を行なうと ともに清浄鋼の製造に努めている.

\section{交献}

1) 新実高保, 阔村正義：鉄之鋼，62 (1976), p.1691

2) 第 27 , 第 28 回西山記念誨座

3) 長降郎, 井上道雄：鉄と鋼，53 (1967)，p. 1393

4) 住友金属: 籁 47 回特殊銅部会資料，1973 年

$5) H$. KNüPPEL and $F$. Oeters: Arch. Eisenhüttenw., 33 (1962), p. 729

6) $Y u, V$. Torakanov and $B, V$. Linchevskil: Steel in English, (1972), p. 367

7 ) $W . M$. Boorstein and $R$. D. Pehlke: Trans. AIME, 245 (1969), p. 1843

8 ）鈴木是明，谷口晃造：鉄と鋼，62（1976)，p.605

9 ) 前川静称, 中川義隆, 福本勝, 谷口昌造: 鉄と 鋼, 55 (1969), S 329

10) 第 12 回西山記念講座

11) $A$. E. Hokansen: "Vacuum metallurgy conference 1963", p.238, 1964, Boston, Amer. Vac. Soc.

12) B. D. MArsh and $W . L$. Heideger: Ind. Eng. Chem. Fundamentals, 4 (1965), p. 129

13）森一美, 佐野正道, 星野秀夫: 鉄上铜, 61 (1975), p. 182

14）神戸製鋼，(高砂)：第 51 回特殊涻部会資料, 1975 年

15）神戸製絧，(滈仯)：等 10 回電気炉部会得 2 分科 会資料 